\title{
$\mathrm{BMC}$
}

Infectious Diseases

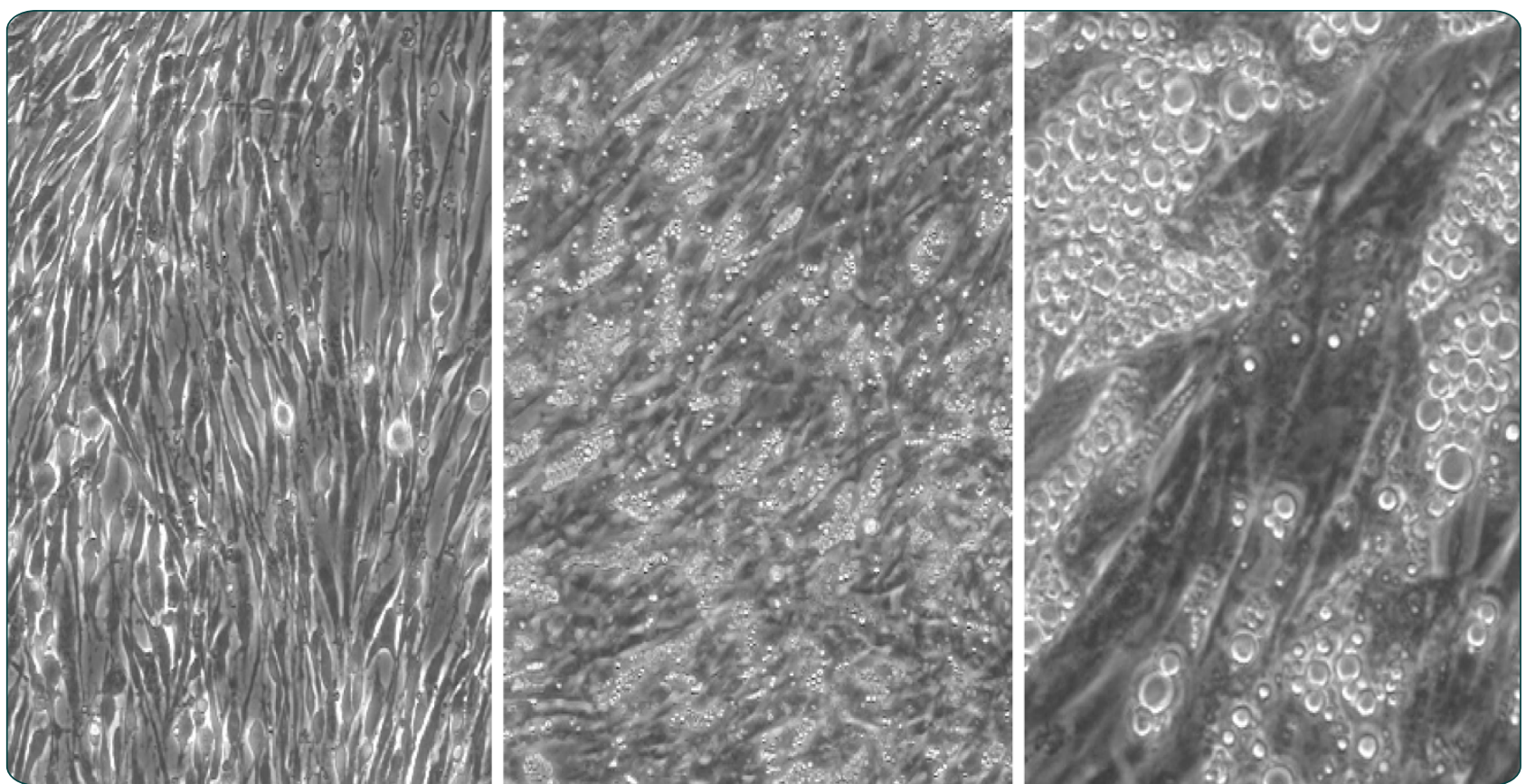

\section{Alterations of leptin in the course of inflammation and severe sepsis}

Behnes et al. 


\title{
Alterations of leptin in the course of inflammation and severe sepsis
}

\author{
Michael Behnes ${ }^{1}$, Martina Brueckmann', Siegfried Lang ${ }^{1}$, Christian Putensen², Joachim Saur ${ }^{1}$, \\ Martin Borggrefe ${ }^{1}$ and Ursula Hoffmann ${ }^{1 *}$
}

\begin{abstract}
Background: The adipokine leptin regulates energy expenditure, vascular function, bone and cartilage growth as well as the immune system and systemic inflammatory response. Several activating effects towards $T$ cells, monocytes, endothelium cells and cytokine production have been reported suggesting a protective role of leptin in the setting of an acute systemic inflammation. However, the pathophysiological role of leptin during severe sepsis is currently not elucidated in detail. This study aims to investigate leptin expression in cultured human adipocytes within an inflammatory model and in patients suffering from severe sepsis and evaluates treatment effects of drotrecogin alpha (activated) (DAA), the recombinant form of human activated protein $C$.
\end{abstract}

Methods: In an in-vitro inflammatory model of adipocyte cell-culture the effect of DAA on leptin mRNA expression was evaluated. Synthesis of mRNA was measured by quantitative polymerase chain reaction (qPCR). Additionally, supernatants of these adipocytes as well as serum levels of adiponectin were measured in blood of 104 severe septic patients by ELISA-method. 26 patients were treated with DAA (DAA+), 78 patients were not treated with DAA (DAA-).

Results: Stimulation of human adipocytes with TNF alpha over 6 and 24 hours resulted in a significant decrease by $46 \%$ and $59 \%$ of leptin mRNA transcripts compared to un-stimulated controls $(p<0.05)$. Leptin levels of supernatants of adipocyte culture decreased by 25\% and 23\% ( $p<0.05)$ after incubation with TNF alpha after 6 and 24 hours. Incubation with DAA at $50 \mathrm{ng} / \mathrm{ml}$ DAA and $5 \mu \mathrm{g} / \mathrm{ml}$ doubled mRNA expression significantly at 24 hours $(p<0.05)$ but not at 6 hours. From day 1 to day 3 of sepsis, leptin levels increased in DAA+ compared to DAApatients $(p<0.10)$.

Conclusions: Leptin appears to be involved in the pathogenesis of a systemic inflammatory response during sepsis. Administration of DAA significantly increased leptin expression. The specific mechanism or even benefit of DAA towards leptin needs further ongoing research.

Keywords: Adipocytes, Drotrecogin alpha (activated), Leptin, mRNA, Sepsis, Supernatants

\section{Background}

Leptin belongs to the so-called adipokines, hormones being secreted in adipocytes of white adipose tissue [1]. Leptin interacts with specific ob-receptors and reveals pleiotropic neurohumoral functions, which regulate appetite and energy expenditure via the hypothalamic-pituitary-adrenal axis, vascular function, bone and cartilage growth, pregnancy as well as the

\footnotetext{
*Correspondence: ursula.hoffmann@umm.de

${ }^{1}$ First Department of Medicine, University Medical Centre Mannheim (UMM), Faculty of Medicine Mannheim, University of Heidelberg,

Theodor-Kutzer-Ufer 1-3, 68167, Mannheim, Germany

Full list of author information is available at the end of the article
}

regulation of the immune system and systemic inflammatory response [2]. Several activating effects towards $\mathrm{T}$ cells, monocytes, endothelium cells and cytokine production have been reported and might suggest both a pro-inflammatory and protective role for leptin in the setting of an acute systemic inflammation $[3,4]$.

Sepsis is defined as a clinical syndrome including an infection and the systemic inflammatory response $[5,6]$. Because of its high incidence, mortality rate and associated costs within the healthcare system sepsis has become a major challenge of today's medicine $[7,8]$. Sepsis emerges to severe sepsis when one or more organ 
dysfunctions reemerge. Individual factors (eg, genetic factors or premorbid health status), extent of infection, and complicating organ dysfunction have a substantial impact on the disease process. Several inflammatory and procoagulant markers have been identified indicating the disease severity in these patients (eg, procalcitonin (PCT), interleukin 6 (IL-6), D-dimer) $[5,6,9]$.

However, the role of leptin during sepsis is not yet fully elucidated. Conflicting results have been reported in which leptin was supposed to be either up- or downregulated or even unchanged during systemic inflammation [10-13]. In addition to its predominant role in the inhibition of blood coagulation, human activated protein $\mathrm{C}$ (APC) plays an important role in the regulation of inflammation [14]. Multiple biological activities of APC have been demonstrated both in clinical and experimental settings, comprising pro-fibrinolytic, immune-modulating and antiapoptotic properties [15-21]. Drotrecogin alpha (activated) (DAA) is the recombinant form of human activated protein $\mathrm{C}$ which was administered patients in our intensive care unit. Therefore we additionally analysed DAA in our inflammatory cell model for possible modulatory effects on leptin levels.

This study aims to investigate the expression of leptin both - in-vitro - in human adipocyte cell-culture within an inflammatory model and - in vivo - in patients suffering from severe sepsis, thereby additionally evaluating the specific treatment effect of drotrecogin alpha (activated) (DAA) on leptin expression.

\section{Methods}

\section{Cell culture of human adipocytes}

Cryopreserved Human White Preadipocytes (HWP) from subcutaneous adipose tissue and all culture media were supplied by Promocell (Heidelberg, Germany). They were cultivated as described by Promocell at $37^{\circ} \mathrm{C}$ in a humidified atmosphere of $95 \%$ air / $5 \% \mathrm{CO}_{2}$. Medium was changed every 2-3 days. Preadipocytes were plated at a density of 5000 cells/cm [2] and cultured to total confluency stage in 6-well plates with $3 \mathrm{~mL}$ growth medium without antibiotics, containing $5 \%$ fetal calf serum. Growth medium was replaced and differentiation medium (including d-Biotin $8 \mu \mathrm{g} / \mathrm{mL}$, Insulin $0.5 \mu \mathrm{g} / \mathrm{mL}$, Dexamethasone $400 \mathrm{pg} / \mathrm{ml}$, IBMX $44 \mu \mathrm{g} / \mathrm{mL}$, L-Thyroxine $9 \mathrm{pg} / \mathrm{ml}$, Ciglitazone $3 \mu \mathrm{g} / \mathrm{mL}$ ) was added for $72 \mathrm{~h}$ to start the differentiation process. To complete differentiation the cells were then cultured for further 12 days with adipocyte nutrition medium (including fetal calf serum 3\%, d-Biotin $8 \mu \mathrm{g} / \mathrm{mL}$, Insulin $0.5 \mu \mathrm{g} / \mathrm{mL}$, Dexamethasone $400 \mathrm{pg} / \mathrm{ml}$ ). During this time lipid droplets developed. Fully differentiated cells at day 15 after starting the differentiation process were preincubated with $1 \mathrm{~mL}$ nutrition medium lacking fetal calf serum and Dexamethasone for $24 \mathrm{~h}$ before starting the experiment. The dosages of TNF alpha and DAA used for the present analyses accorded to our established protocols within our working group, which have formerly been published, respectively in an inflammatory model with endothelial cells [20,21]. Several dosages of the highly selective and efficient stimulator TNF alpha resulted in $1 \mathrm{ng} / \mathrm{ml}$ as a concentration leading to sub-maximal effects on cytokines like IL-8 or IL-6. Drotrecogin alpha (activated) was added to yield final concentrations of $50 \mathrm{ng} / \mathrm{ml}$ and $5 \mu \mathrm{g} / \mathrm{ml}$. $1 \mathrm{~h}$ later TNF alpha was accordingly added for $1 \mathrm{ng} / \mathrm{ml}$. Cells were incubated for $6 \mathrm{~h}$ and $24 \mathrm{~h}$ and harvested to prepare total RNA. Supernatants of cell medium were frozen for quantification of leptin by ELISA. Treatment with DAA ( $50 \mathrm{ng} / \mathrm{ml}$ or $5 \mu \mathrm{g}$ / $\mathrm{ml})$ and TNF alpha $(1 \mathrm{ng} / \mathrm{ml})$ did not affect adipocyte viability, as assessed by trypan blue exclusion (90\% viable cells, no difference to untreated controls).

\section{mRNA expression of leptin}

For quantitative evaluation of DAA-dependent leptin mRNA steady-state expression in adipocyte cultures, total RNA was prepared by using the RNeasy mini column kit (Qiagen, Hilden, Germany), including DNAse treatment. Three micrograms of RNA were reverse transcribed and converted to $\mathrm{CDNA}$ with oligo $(\mathrm{dT})_{15}$ primers using AMV reverse transcriptase according to standard protocols (Roche Applied Science, Germany, AMV Cat. No. 11495062001). The cDNA was amplified by quantitative PCR (qPCR) on the ABI 7000 realtime system (Applied Biosystems, Foster City, USA) using a qPCR-mix with hot start Taq DNA polymerase, SYBR-Green and enzyme system which reduces carryover DNA contamination $\left(\mathrm{SYBR}^{\circledR}\right.$ GreenER $^{\mathrm{TM}}$, Invitrogen, Cat.No.11760500) in the presence of sense and antisense primers (400 nM each). The senseand antisense-primers for leptin were supplied from SABiosciences Corp. (Cat. No. PPH00581A). GAPDH as housekeeping gene was analyzed using primers as follows: [22] sense 5'-TGCACCACCAACTGCTTAGC-3', antisense 5'-GGCATGGACTGTGGTCATGAG-3'. The qPCR condition consisted of $50^{\circ} \mathrm{C}$ for 2 min (reduction of DNA carryover contamination), $95^{\circ} \mathrm{C}$ for $10 \mathrm{~min}$ followed by 40 cycles of $95^{\circ} \mathrm{C}$ for $15 \mathrm{sec}$ and $60^{\circ} \mathrm{C}$ for $1 \mathrm{~min}$, followed by melting-curve analysis to verify the correctness of the amplicon. Relative quantification of leptin mRNA expression was calculated as follows: The expression of leptin mRNA relative to the housekeeping gene GAPDH in samples from cells treated with DAA or untreated (Control) was calculated by the $\Delta \Delta \mathrm{CT}$ method, based on the threshold cycle $(\mathrm{CT})$, as fold change $=2^{-\Delta(\Delta \mathrm{CT})}$, where $\Delta \mathrm{CT}=$ $\mathrm{CT}_{\text {leptin }}-\mathrm{CT}_{\mathrm{GAPDH}}$ and $\Delta(\Delta \mathrm{CT})=\Delta \mathrm{CT}_{\mathrm{DAA}}-\Delta \mathrm{CT}$ Control $[23,24]$. Efficiencies of the amplification reactions were calculated with a typical sample analysing the slope of the regression line of a 10 -fold dilution series of cDNA $(\log 10)$ versus CT: Efficiency $=10^{-1 / \text { slope }}$. Only primer pairs that showed an amplification efficiency between $1.90-2.05$ 
(90-105\%) and a coefficient of correlation (r) between $0.90-1.0$ were used for quantification [25]. For verification of the correct length of amplification products, they were analysed on an ethidium bromide stained $2 \%$ agarose gel. All cell-culture experiments have been repeated at least twice to guarantee repeatability.

\section{Study population}

A total of 104 patients suffering from severe sepsis were prospectively enrolled at the First Department of Medicine, University Medical Centre Mannheim (UMM) (Germany) and at the Department of Anaesthesiology and Intensive Care Medicine, University Hospital Bonn (Germany) from March 2001 until October 2006. The study was carried out according to the principles of the declaration of Helsinki and was approved by the medical ethics commission II of the Medical Faculty Mannheim, University of Heidelberg, Germany. Written informed consent was obtained from all participating patients or their legal representatives.

The diagnosis of severe sepsis was based on criteria established by the American College of Chest Physicians and the Society of Critical Care Medicine Consensus Conference 1992: [5] Patients presented with a proven infection, three or more criteria of the systemic inflammatory response syndrome (SIRS criteria) and at least 1 of the following newly developed, sepsis-induced organ failures: cardiovascular organ failure with need for vasopressors, pulmonary organ failure defined as $\mathrm{PaO}_{2} / \mathrm{FiO}_{2}<250$, renal organ failure with urine output $<0,5 \mathrm{ml} / \mathrm{kg} / \mathrm{h}$, hematological organ failure with platelet count $<80000 / \mathrm{mm}$ [3] or an unexplained metabolic acidosis with $\mathrm{pH}<7.3$ and lactate levels $>1.5$ times of the upper limit of normal. Sepsis-induced organ failures in these patients were strongly connected to infection and were present for less than $24 \mathrm{~h}$. Severity of sepsis was defined by the Acute Physiology and Chronic Health Evaluation II (APACHE II) score [26].

Out of a total of 104 patients suffering from severe sepsis 26 patients were treated with drotrecogin alpha (activated) (DAA) and 78 patients were not treated. The decision to treat patients with DAA or without was based on site-specific treatment modalities concerning the inclusion and exclusion criteria for the administration of DAA [27]. Twenty-six septic patients received a 96-hour infusion of DAA (XIGRIS ${ }^{\circledR}$ : $24 \mu \mathrm{g}$ per $1 \mathrm{~kg}$ body weight per hour). 78 patients with severe sepsis did not receive DAA because of contraindications for drotrecogin alpha (activated) such as platelet count $30000 / \mathrm{mm}$, need for therapeutic anticoagulation with heparin, increased risk of bleeding, recent gastrointestinal bleeding, or stroke within the last 3 months [28]. Additionally 45 healthy humans were included to serve as a control group.
Baseline characteristics, such as APACHE II scores, body mass index (BMI), creatinine levels, white blood cell count, platelet count, $\mathrm{C}$-reactive protein (CRP), bilirubin, international normalized ratio (INR), activated partial thromboplastin time (a-PTT), antithrombin III (AT III), D-dimer as well as body temperature were determined on day 1 of severe sepsis. Total clinical follow-up lasted over 28 days and defined clinical outcomes such as death or survival were documented.

\section{Plasma samples and leptin assay}

Blood samples were obtained by venipuncture into serum monovettes ${ }^{\circledR}$ within the first $24 \mathrm{~h}$ after the diagnosis of severe sepsis (day 1 ), as well as on day 3 and 5 of severe sepsis. Within 30 minutes all blood samples were centrifuged at $1000 \times \mathrm{g}$ at $4^{\circ} \mathrm{C}$ for 15 minutes. Serum was separated, frozen and stored at $-80^{\circ} \mathrm{C}$.

Leptin measurement was performed with a solid phase two-site immunosorbent assay (ELISA) (Quantikine ${ }^{\circledR}$ human leptin immunoassay, $R \& D$ Systems Inc., Minneapolis, USA) [29].

\section{Statistical analysis}

For data with normal distribution, the Student $t$ test was applied. Otherwise, the Mann-Whitney $U$ test was used as a nonparametric test. Deviations from a Gaussian distribution were tested by the Kolmogorov-Smirnov test. To generate hypotheses we used multiple t-tests with Holm-Bonferroni adjustments. For cell culture experiments the most important groups were specified in advance to be compared by statistical analysis: i) Control versus TNF alpha; ii) TNF alpha versus TNF alpha + DAA $50 \mathrm{ng} / \mathrm{mL}$; iii) TNF alpha + DAA $50 \mathrm{ng} / \mathrm{mL}$ versus TNF alpha + DAA $5 \mu \mathrm{g} / \mathrm{mL}$. Pearson's correlation was used for normally distributed data. Spearman's rank correlation was used for nonparametric data. Noncontinuous variables were analyzed by the use of a $2 \times 2$ table and Fisher's exact test. Data are presented as mean \pm standard deviation (SD) or standard error of mean (SEM) as indicated. Values of $\mathrm{P}<0.10$ (two-tailed) were considered tending to be significant and $\mathrm{P}<0.05$ (two-tailed) were considered statistically significant. The calculations were performed with InStat (GraphPad Software) and SPSS software (SPSS Software $\mathrm{GmbH}$ ).

\section{Results}

\section{In-vitro results}

In-vitro analyses showed final cell differentiation of human adipocytes after 15 days of cell growth (Figure 1a-c). Stimulating human adipocytes with tumor necrosis factor alpha alone (concentration TNF alpha, $1 \mathrm{ng} / \mathrm{ml}$ ) over 6 hours resulted in leptin mRNA transcripts decreased by $46 \%$ compared to un-stimulated controls $(\mathrm{p}<0.05)$ (Figure 2). Adding DAA at $50 \mathrm{ng} / \mathrm{ml}$ 


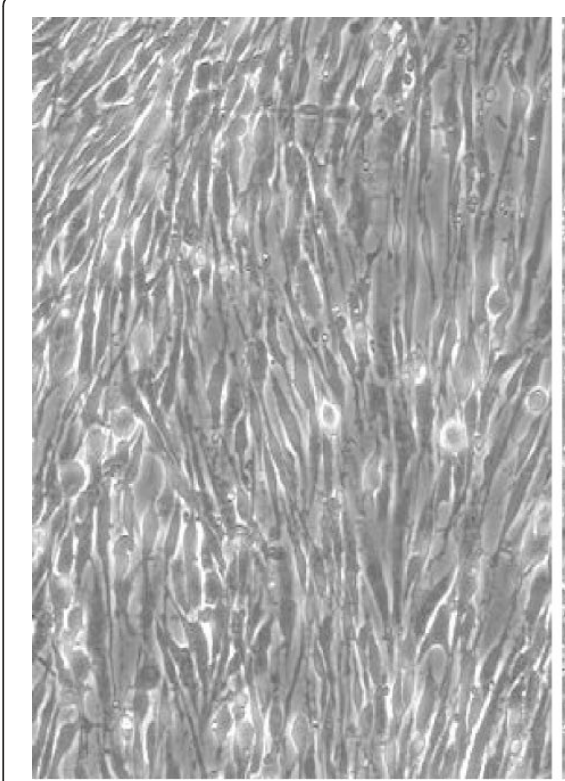

a

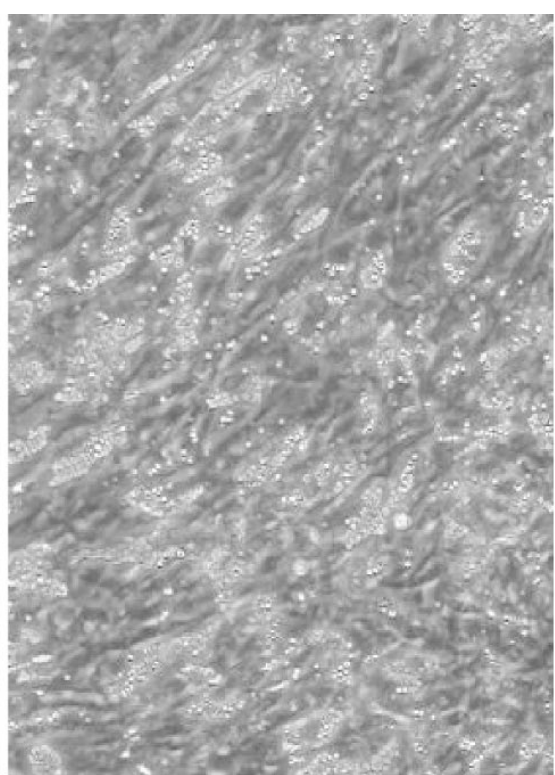

b

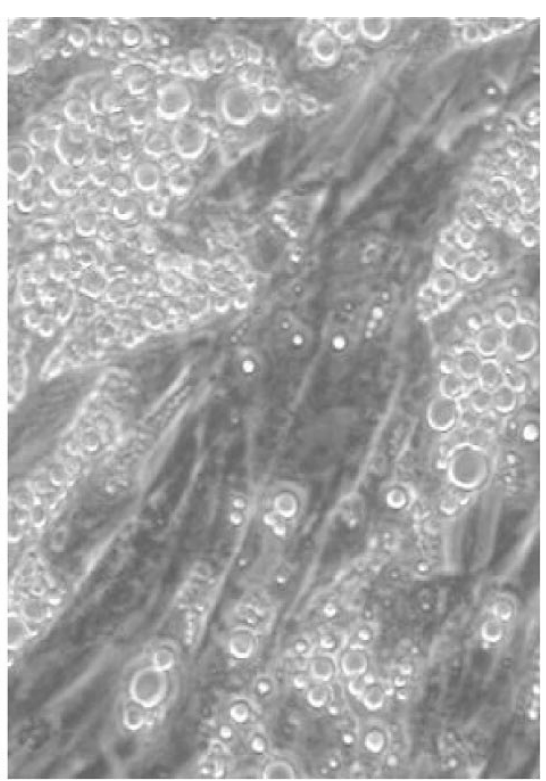

c

Figure 1 Confluent cultures of undifferentiated preadipocytes (a) and mature adipocytes after differentiation for 15 days (b,c). The high amount of fat droplets, visible as light globules $(b, c)$, demonstrates the cells being differentiated to mature adipocytes. Cells were photographed with $100 \times(\mathbf{a}, \mathbf{b})$ and $400 \times$ (c) magnification.

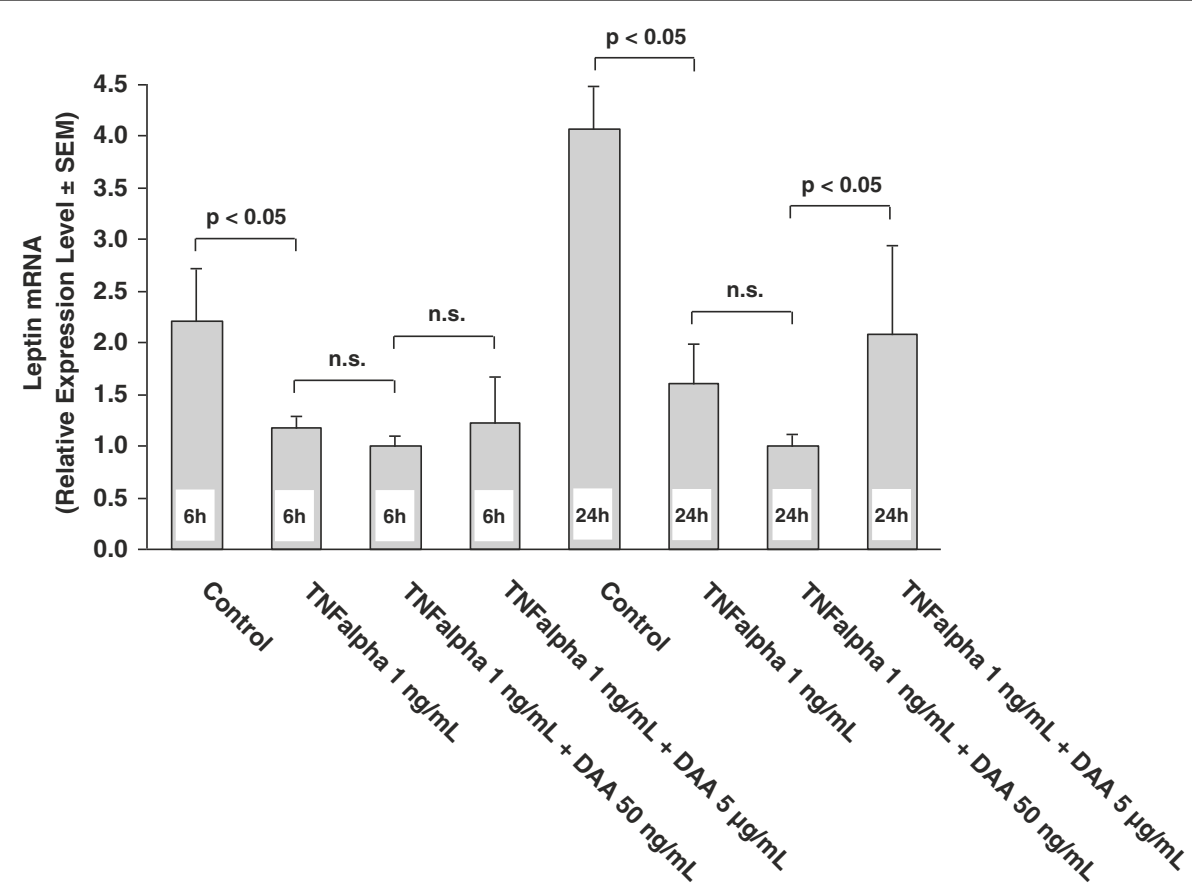

Figure 2 Leptin mRNA expression was significantly decreased after 6 and 24 hours of stimulation with $1 \mathrm{ng} / \mathrm{ml}$ TNF alpha $(\mathrm{p}<0.05)$ in human adipocytes. Drotrecogin alpha (activated) (DAA) dose-dependently increased leptin mRNA levels after 24 hours from DAA $50 \mathrm{ng} / \mathrm{ml}$ to DAA $5 \mu \mathrm{g} / \mathrm{ml}(\mathrm{p}<0.05)$, but at 6 hours no significant change could be detected. Significances (n.s. = not significant) of t-tests with HolmBonferroni adjustments for multiple comparisons are indicated. Only the relevant in advance specified group comparisons were analysed. Data are presented as mean with standard error of mean (SEM). 
or $5 \mu \mathrm{g} / \mathrm{ml}$ to TNF alpha at $1 \mathrm{ng} / \mathrm{ml}$, a significant change of leptin mRNA expression could not be detected (Figure 2). Stimulating human adipocytes with TNF alpha alone at the same concentration of $1 \mathrm{ng} / \mathrm{ml}$ for a longer time of 24 hours resulted in leptin mRNA transcripts decreased by $59 \%$ compared to un-stimulated controls $(\mathrm{p}<0.05$ ) (Figure 2). Adding DAA at $50 \mathrm{ng} / \mathrm{ml}$ or $5 \mu \mathrm{g} / \mathrm{ml}$ to TNF alpha at $1 \mathrm{ng} / \mathrm{ml}$, a significant upregulation of leptin mRNA expression was detected after 24 hours from DAA at $50 \mathrm{ng} / \mathrm{ml}$ to $5 \mu \mathrm{g} / \mathrm{ml}(\mathrm{p}<0.05)$ (Figure 2).

Similar expression profiles as with leptin mRNA were seen when measuring leptin levels out of supernatants of the adipocytes by ELISA. Leptin levels of supernatants of adipocyte culture decreased by $25 \%(\mathrm{p}<0.05)$ after incubation with TNF alpha alone after 6 hours (Figure 3). After 6 hours incubation with TNF alpha at $1 \mathrm{ng} / \mathrm{ml}$ and DAA at $50 \mathrm{ng} / \mathrm{ml}$ or $5 \mu \mathrm{g} / \mathrm{ml}$ leptin levels increased from DAA at $50 \mathrm{ng} / \mathrm{ml}$ to $5 \mu \mathrm{g} / \mathrm{ml}(\mathrm{p}<0.05)$ (Figure 3). After 24 hours leptin levels significantly decreased by $23 \%$ after incubation with TNF alpha alone $(\mathrm{p}<0.05)$ (Figure 3$)$. But a significant change of leptin levels from DAA at $50 \mathrm{ng} / \mathrm{ml}$ to $5 \mu \mathrm{g} / \mathrm{ml}$ could not be detected after 24 hours (Figure 3).

Treatment with DAA (50 ng/ml or $5 \mu \mathrm{g} / \mathrm{ml}$ ) and TNF alpha $(1 \mathrm{ng} / \mathrm{ml})$ did not affect adipocyte viability, as assessed by trypan blue exclusion ( $90 \%$ viable cells, no difference to untreated controls; data not shown).

\section{In-vivo results}

Baseline characteristics of 104 patients suffering from severe sepsis are given in Table 1 . Mean age of all study patients was 64 years. Patients treated with DAA $(\mathrm{n}=26)$ were younger than patients not treated $(\mathrm{n}=78)$ ( 57 years vs. 67 years; $\mathrm{p}=0.002$ ). The most common primary site of infection was the lung $(n=51)$, followed by cardiac $(\mathrm{n}=12)$ and intra-abdominal infections $(\mathrm{n}=7)$ $(\mathrm{p}=0.3)$. The mean APACHE II score was $28.3(\mathrm{SD}=$ 5.4). Mean BMI levels were similar in all patient groups $(\mathrm{DAA}+$, mean $=25.2, \pm \mathrm{SEM}=2.5, \mathrm{DAA}-$, mean $=26.6$, \pm SEM $=0.9, \mathrm{p}=0.6$ ).

Leptin serum levels significantly correlated with age, body temperature, BMI and APACHE II score. Additionally leptin levels inversely correlated with adiponectin, and correlated positively with white blood cells, antithrombin III, interleukin 6 and creatinine (Table 2). However, there were no significant differences of leptin levels in patients with impaired renal function (defined as a serum creatinine value above $1.1 \mathrm{mg} / \mathrm{dl}$ ) compared to patients with a regular renal function (defined as a serum creatinine value below or equal than $1.1 \mathrm{mg} / \mathrm{dl}$ ) (patients with renal failure, leptin mean $29282 \mathrm{pg} / \mathrm{ml}, \pm$ SEM $4398 \mathrm{pg} / \mathrm{ml}, \mathrm{n}=75$; patients without renal failure, leptin mean $21896 \mathrm{pg} / \mathrm{ml}, \pm 5631 \mathrm{pg} / \mathrm{ml}, \mathrm{n}=29 ; \mathrm{p}=0.3)$. No association was found between leptin and $C$ reactive protein (Table 2).

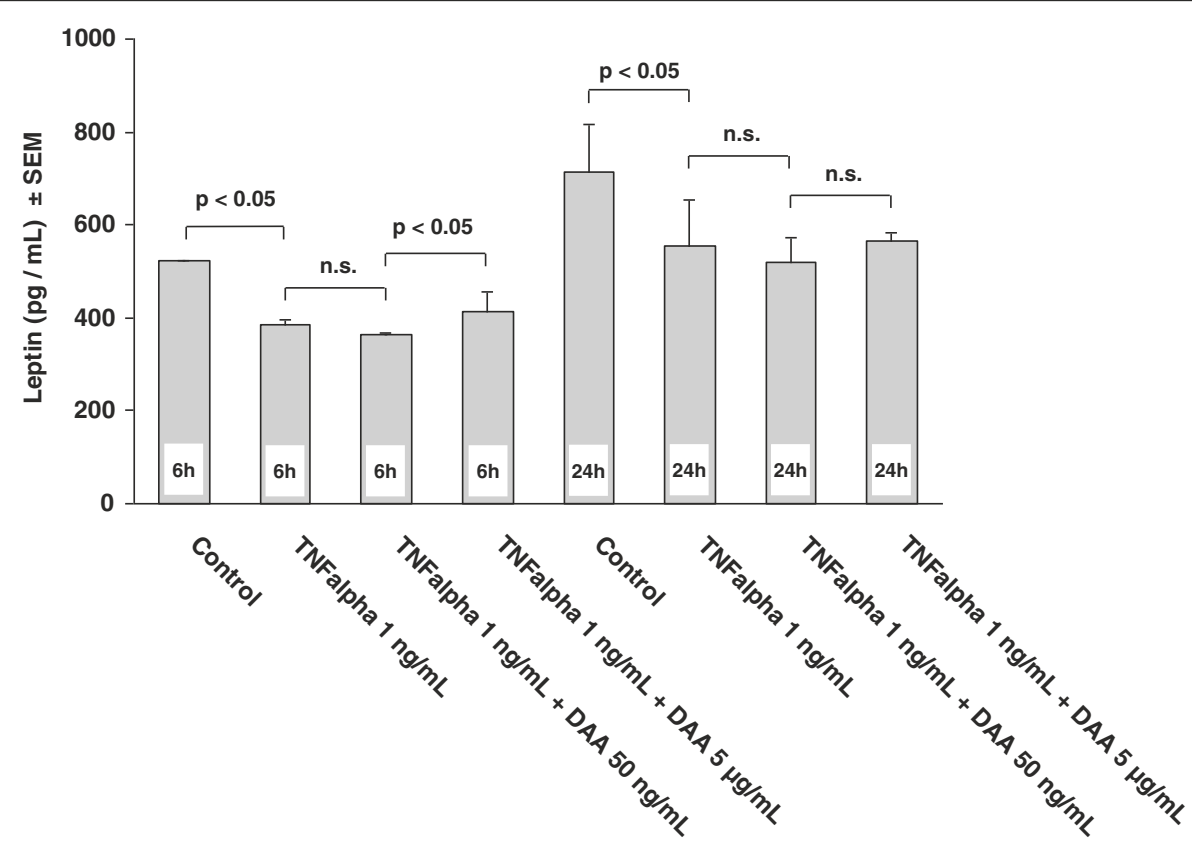

Figure 3 Leptin levels out of supernatants of the adipocytes cell culture measured by ELISA showed decreased levels of leptin after incubation with TNF alpha for 6 and 24 hours $(p<0.05)$. Increasing levels of leptin were observed after 6 hours of incubation according to the applied dosages of DAA (50 $\mathrm{ng} / \mathrm{ml}$ and $5 \mu \mathrm{g} / \mathrm{ml}$ ). Significances (n.s. = not significant) of t-tests with Holm-Bonferroni adjustments for multiple comparisons are indicated. Only the relevant in advance specified group comparisons were analysed. Data are presented as mean with standard error of mean (SEM). 
Table 1 Baseline characteristics of 104 patients suffering from severe sepsis at day 1

\begin{tabular}{|c|c|c|c|c|}
\hline & $\begin{array}{l}\text { All patients } \\
(n=104)\end{array}$ & $\begin{array}{l}\text { DAA + } \\
(n=26)\end{array}$ & $\begin{array}{l}\text { DAA - } \\
(n=78)\end{array}$ & $\begin{array}{c}p \\
\text { value } \dagger\end{array}$ \\
\hline Age $($ years)* & $64.0 \pm 13.5$ & $56.6 \pm 15.0$ & $66.5 \pm 12.1$ & 0.002 \\
\hline \multicolumn{5}{|l|}{ Gender $(n)$} \\
\hline Male & 62 & 16 & 46 & 0.8 \\
\hline Female & 42 & 10 & 32 & \\
\hline Body mass index (BMI) * & $26.4 \pm 0.8$ & $25.2 \pm 2.5$ & $26.6 \pm 0.9$ & 0.6 \\
\hline Heart rate $($ beats $/ \mathrm{min}) *$ & $84 \pm 23.6$ & $85 \pm 20.8$ & $84 \pm 24.5$ & 0.76 \\
\hline APACHE II score * & $28.3 \pm 5.4$ & $28.6 \pm 6.5$ & $28.1 \pm 5.0$ & 0.9 \\
\hline \multicolumn{5}{|l|}{ Primary site of infection (n) } \\
\hline Lung & 51 & 10 & 41 & \\
\hline Urinary & 6 & 2 & 4 & \\
\hline Cerebral & 5 & 2 & 3 & \\
\hline Cardiac & 12 & 4 & 8 & 0.3 \\
\hline Intra-abdominal & 7 & - & 7 & \\
\hline Skin & 2 & - & 2 & \\
\hline Unknown & 21 & 8 & 13 & \\
\hline $\operatorname{CRP}(\mathrm{mg} / \mathrm{l})^{*}$ & $164 \pm 126$ & $206 \pm 151$ & $151 \pm 115$ & 0.2 \\
\hline Creatinine $(\mathrm{mg} / \mathrm{dl})^{*}$ & $2.6 \pm 2.1$ & $3.0 \pm 2.3$ & $2.5 \pm 2.0$ & 0.2 \\
\hline White blood cells $\left(10^{9} /\right)^{*}$ & $16.4 \pm 8.0$ & $16.0 \pm 9.7$ & $16.5 \pm 7.5$ & 0.4 \\
\hline Platelets $\left(10^{9} /\right)^{*}$ & $210 \pm 117$ & $202 \pm 115$ & $213 \pm 118$ & 0.5 \\
\hline aPTT $(\mathrm{sec})^{*}$ & $40.7 \pm 24.4$ & $42.2 \pm 25.5$ & $40.2 \pm 24.2$ & 0.4 \\
\hline Antithrombin III (\%)* & $63.5 \pm 19.5$ & $61.4 \pm 17.1$ & $64.3 \pm 20.6$ & 0.8 \\
\hline D-dimer $(\mu \mathrm{g} / \mathrm{ml})^{*}$ & $5.0 \pm 3.8$ & $3.0 \pm 2.0$ & $5.5 \pm 4.1$ & 0.4 \\
\hline Bilirubin $(\mathrm{mg} / \mathrm{dl})^{*}$ & $1.7 \pm 1.8$ & $2.6 \pm 2.3$ & $1.4 \pm 1.5$ & 0.04 \\
\hline Death (n) & 53 & 17 & 36 & 0.9 \\
\hline
\end{tabular}

* Data are presented as mean \pm standard deviation (SD).

$\dagger p$ values are calculated for the comparison between DAA+ patients with DAA- patients.

Table 2 Correlations between leptin levels and clinical indices at day 1 of severe sepsis

\begin{tabular}{|c|c|c|c|c|c|c|}
\hline & \multicolumn{2}{|c|}{ All patients $(n=104)$} & \multicolumn{2}{|c|}{ DAA $(n=26)$} & \multicolumn{2}{|c|}{ No $\operatorname{DAA}(n=78)$} \\
\hline & $r$ & p-value & $r$ & p-value & $r$ & $\mathrm{p}$-value \\
\hline Age & 0.25 & 0.01 & 0.34 & 0.09 & 0.26 & 0.02 \\
\hline Body temperature & 0.27 & 0.007 & 0.57 & 0.005 & 0.28 & 0.02 \\
\hline Body mass index (BMI) & 0.40 & 0.01 & 0.49 & 0.4 & 0.41 & 0.01 \\
\hline APACHE I| score & 0.28 & 0.03 & 0.34 & 0.15 & 0.32 & 0.04 \\
\hline Adiponectin & -0.28 & 0.04 & -0.26 & 0.19 & -0.33 & 0.003 \\
\hline White blood cell count & 0.19 & 0.06 & -0.14 & 0.52 & 0.20 & 0.08 \\
\hline CRP & -0.06 & 0.57 & 0.15 & 0.49 & -0.09 & 0.46 \\
\hline Interleukin 6 & -0.09 & 0.37 & 0.53 & 0.009 & -0.02 & 0.88 \\
\hline Hemoglobin & 0.19 & 0.06 & 0.44 & 0.03 & 0.12 & 0.28 \\
\hline Hematocrit & 0.20 & 0.04 & 0.46 & 0.02 & 0.15 & 0.20 \\
\hline Platelets & 0.21 & 0.03 & 0.16 & 0.4 & 0.15 & 0.18 \\
\hline Creatinine & 0.22 & 0.03 & 0.12 & 0.6 & 0.32 & 0.005 \\
\hline Antithrombin III & 0.31 & 0.03 & 0.6 & 0.02 & 0.35 & 0.04 \\
\hline
\end{tabular}


As demonstrated in Figure 4, patients suffering from severe sepsis without treatment of DAA revealed significantly higher serum concentrations of leptin compared to healthy controls $(\mathrm{n}=45$, mean $=12116 \mathrm{pg} / \mathrm{ml}, \pm$ $\mathrm{SEM}=1945 \mathrm{pg} / \mathrm{ml}$ ) (leptin concentrations, Day 1: DAA-, mean $=30175 \mathrm{pg} / \mathrm{ml}, \pm \mathrm{SEM}=4203 \mathrm{pg} / \mathrm{ml}$. Day 3: DAA-, mean $=32670 \mathrm{pg} / \mathrm{ml}, \pm \mathrm{SEM}=6173 \mathrm{pg} / \mathrm{ml}$. Day 5: DAA-, mean $=32731 \mathrm{pg} / \mathrm{ml}, \pm \mathrm{SEM}=6220 \mathrm{pg} / \mathrm{ml})(\mathrm{p}<0.05)$.

At the beginning of treatment with DAA (day 1) leptin levels showed a tendency $(\mathrm{p}<0.10)$ to be lower (day 1 : $\mathrm{DAA}+$, mean $=18991 \mathrm{pg} / \mathrm{ml}, \pm \mathrm{SEM}=6009 \mathrm{pg} / \mathrm{ml}, \mathrm{nc}=$ 26) compared to patients without DAA (Figure 4). From day 1 to day 3 of sepsis, leptin levels increased in patients treated with DAA compared to patients without treatment of DAA $(\mathrm{p}<0.10)$ (leptin concentrations, Day 1: DAA+, mean $=18991 \mathrm{pg} / \mathrm{ml}, \pm \mathrm{SEM}=6009 \mathrm{pg} / \mathrm{ml}$. Day 3: DAA + , mean $=57315 \mathrm{pg} / \mathrm{ml}, \pm \mathrm{SEM}=17075 \mathrm{pg} / \mathrm{ml}$. Day 5: DAA + , mean $=54980 \mathrm{pg} / \mathrm{ml}, \pm$ SEM $=17660 \mathrm{pg} / \mathrm{ml}$ ).

There was no difference of leptin concentrations between patients surviving 28 days follow-up (mean $=26073 \mathrm{pg} / \mathrm{ml}$, $\pm \mathrm{SEM}=4704 \mathrm{pg} / \mathrm{ml}, \mathrm{n}=51$ ) compared to those who were deceased $($ mean $=28824 \mathrm{pg} / \mathrm{ml}, \quad \pm \mathrm{SEM}=5442 \mathrm{pg} / \mathrm{ml}$, $\mathrm{n}=53)(\mathrm{p}>0.10)$.

\section{Discussion}

This study investigated the expression of leptin both in vitro - within an inflammatory model of human cultured adipocytes and - in vivo - in patients suffering from severe sepsis and additionally evaluated the specific treatment effect of drotrecogin alpha (activated) (DAA).
Leptin mRNA and protein expression was downregulated by TNF alpha after 6 and 24 hours of incubation in human adipocytes. But this effect seems not to be due to a reduced number of viable cells because of TNF alpha treatment: Treatment with DAA (50 ng/ml or $5 \mu \mathrm{g} / \mathrm{ml}$ ) and TNF alpha (1 ng/ml) did not affect adipocyte viability, as assessed by trypan blue exclusion. Moreover, administration of DAA $(50 \mathrm{ng} / \mathrm{ml}$ or $5 \mu \mathrm{g} / \mathrm{ml})$ in the presence of TNF alpha ( $1 \mathrm{ng} / \mathrm{ml})$ up-regulated leptin mRNA and protein expression in a dose dependent way at 24 hours. In patients suffering from severe sepsis leptin serum levels remained at the same level from days 1 to 5 in those patients without treatment of DAA. However, in patients treated with DAA leptin serum levels increased from day 1 to day 3 day of severe sepsis during the infusion of DAA over 96 hours. Leptin serum levels were inversely correlated with adiponectin and positively correlated with APACHE II score, body temperature, white blood cell count and interleukin 6.

The present analysis confirmed preliminary reports demonstrating decreased mRNA expression of leptin following TNF alpha stimulation within an in-vitro inflammatory model [30-34]. However, conflicting results have been obtained from cell cultures demonstrating an up-regulation of leptin mRNA expression after stimulation with TNF alpha [35,36]. These varieties might in part be explained by the use of different cell species, anatomical localization of the fat tissue and the duration of exposure to the stimulating cytokines [32]. Hence, mRNA transcription was even

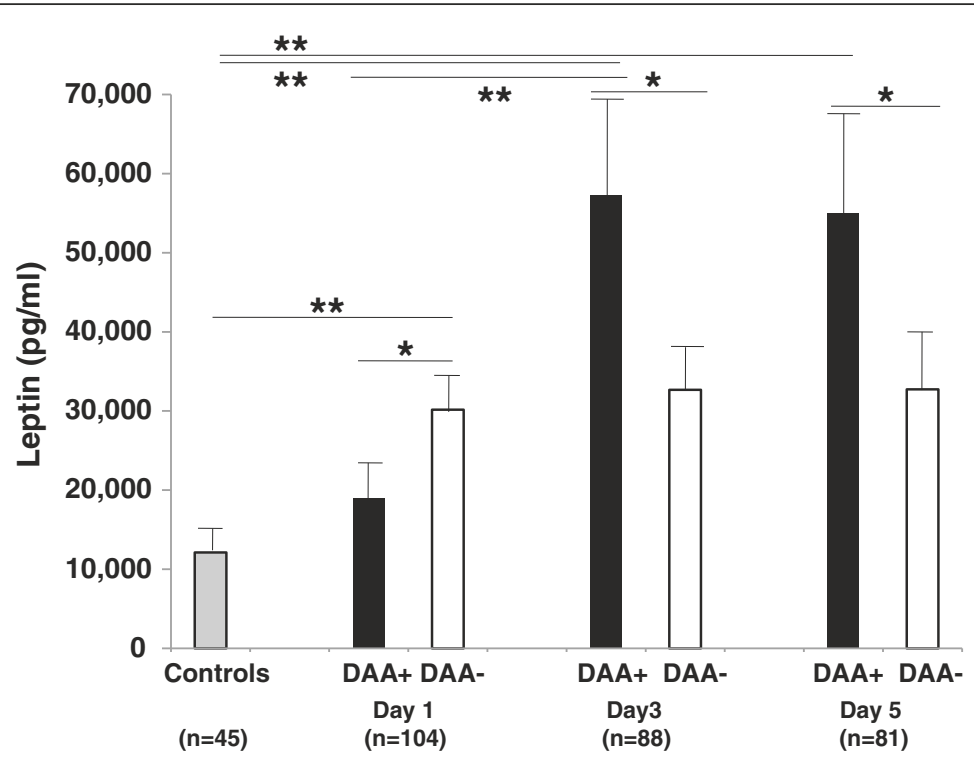

Figure 4 Treating patients with DAA resulted in an increase in leptin levels after 96 hours of DAA infusion compared to patients without treatment of DAA from day 1 to day 3 and 5 ( $p<0.05$ ) (leptin concentrations, Day 1: DAA+, mean = 18991 pg/ml, \pm SEM =6009 pg/ml. Day 3: DAA+, mean $=57315 \mathrm{pg} / \mathrm{ml}, \pm \mathrm{SEM}=17075 \mathrm{pg} / \mathrm{ml}$. Day 5: DAA+, mean $=54980 \mathrm{pg} / \mathrm{ml}, \pm \mathrm{SEM}=17660 \mathrm{pg} / \mathrm{ml})$. Significances of t-tests with Holm-Bonferroni adjustments for multiple comparisons are indicated, otherwise no significance could be reached. Data are presented as mean with standard error of mean (SEM). * $p<0.10,{ }^{* *} p<0.05$. 
more down-regulated after longer incubation of 24 hours compared to 6 hours (59\% vs. 46\%).

In accordance with recently published data we could demonstrate increasing levels of leptin in patients suffering from severe sepsis compared to healthy controls [11,37-41] and showed several correlations with established clinical markers of sepsis. Therefore our observations support evidence that leptin appears to be involved in the pathogenesis and the course of a systemic inflammatory response during sepsis. Interestingly, with regard to the body of literature it was shown that leptin itself increases the production of TNF alpha or Interleukin 6 from macrophages [42].

DAA has been shown to reveal antithrombotic, profibrinolytic, anti-inflammatory and antiapoptotic properties $[27,28]$. However, no data currently exist, whether DAA influences the release of the adipokine leptin. To the best of our knowledge this study is the first to investigate the influence of DAA on leptin expression. It could have been demonstrated that administration of DAA increases the amount of leptin mRNA and protein expression over time in human adipocytes and furthermore significantly increases leptin serum levels in patients suffering from severe sepsis after 96 hours administration of DAA.

Therefore, the present findings might reveal another effect of DAA during sepsis, i.e. the up-regulation of the hormone leptin under circumstances of ongoing systemic inflammation. Several in-vitro studies already demonstrated specific anti-inflammatory effects of DAA, e.g. inhibition of transcription factor NF-kappa B in isolated mononuclear cells or the inhibition of macrophage inflammatory protein-1 (MIP-1-alpha), monocyte chemoattractant protein-1 (MCP-1), neopterin $[19,43,44]$ or up-regulation of adiponectin [45]. However, the role of specifically leptin during severe sepsis is not yet completely understood. It could have been demonstrated that patients surviving an acute sepsis revealed increased levels of leptin, whereas leptin correlated with the disease severity and is an independent predictor of death $[37,38,41]$. Shapiro et al. [46] postulated that leptin might be able to pronounce endothelial dysfunction during sepsis and therefore worsens outcome of the disease. However, increases of the soluble leptin receptor (SLR) were explained as a compensatory anti-inflammatory mechanism.

\section{Limitations}

The exact mechanisms contributing to increased leptin mRNA and protein expressions after administration of DAA in human adipocytes and patients suffering from severe sepsis were not determined in this study. However, we performed cell culture experiments with adipocytes in order to confirm our clinical findings in septic patients with a more straightforward system and proving the involvement of adipocytes. Instead of LPS we used TNF alpha as a more selective and efficient proinflammatory stimulus for sepsis according to our established protocols, respectively in an inflammatory model with endothelial cells having been published already $[20,21]$. It was our intention to apply the same conditions as in the above mentioned inflammatory models in order to guarantee comparability of our own experimental approach. However, TNF alpha serum levels were not measured in our septic patients. Regarding clinical benefits of septic patients increased leptin levels could not show a survival benefit over 28-days follow-up in our study. Nevertheless, our results need to be confirmed by ongoing basic research analyses and larger prospective clinical studies to explain the more detailed mechanisms beyond our findings.

\section{Conclusions}

Taken together, it has been demonstrated that leptin mRNA and -protein expression is down-regulated by TNF alpha in human adipocytes. Administration of DAA up-regulated leptin expression over time and increasing applied dosages of DAA. Accordingly, patients suffering from severe sepsis revealed increased leptin serum levels, while patients treated with DAA revealed increasing leptin serum levels after complete treatment with DAA (i.e. 96 hours infusion) at day 3 and 5 compared to untreated septic patients. Therefore, our results support the hypothesis that leptin might be involved in the pathogenesis of a systemic inflammatory response during sepsis possibly acting as an anti-inflammatory protein. The specific mechanism or even benefit of DAA administration in the time course of sepsis towards leptin needs further ongoing research.

\section{Abbreviations}

APACHE II: Acute Physiology and Chronic Health Evaluation II; aPTT: Activated partial thromboplastin time; AT III: Antithrombin III; BMI: Body mass index; CRP: C-reactive protein (CRP); CVD: Central venous pressure; DAA: Drotrecogin alpha (activated); ELISA: Enzyme-Linked Immunosorbent Assay; ICU: Intensive care unit; INR: International normalized ratio; LPS: Lipopolysaccheride; mRNA: Messenger ribonucleic acid; qPCR: Quantitative polymerase chain reaction; SD: Standard deviation; SEM: Standard error of mean; TNF alpha: Tumor necrosis factor alpha.

\section{Competing interests}

The authors declare that they have no competing interests. This study is part of a registered clinical trial (ClinicalTrials.gov Identifier: NCT00222222).

\section{Authors' contributions}

MBe: study design, data analysis, manuscript preparation and review; SL: carried out the cell culture experiments, data analysis and manuscript review; $\mathrm{MBr}$, JS, MBo: study advice, manuscript review; CP: study design and manuscript review; UH: conceived the study, enrolled study patients and reviewed the manuscript. All authors read and approved the final manuscript. 


\section{Author's information}

+Martina Brueckmann is an employee of Boehringer Ingelheim $\mathrm{GmbH}$ \& Co. KG and a lecturer of the Medical Faculty Mannheim, University of Heidelberg, Germany.

\section{Acknowledgement}

We are grateful to Claudia Liebetrau for their excellent laboratory technical assistance.

\section{Author details}

${ }^{1}$ First Department of Medicine, University Medical Centre Mannheim (UMM) Faculty of Medicine Mannheim, University of Heidelberg,

Theodor-Kutzer-Ufer 1-3, 68167, Mannheim, Germany. ${ }^{2}$ Department of Anesthesiology and Intensive Care Medicine, University of Bonn, Sigmund-Freud-Strasse 25, 53127, Bonn, Germany.

Received: 29 November 2011 Accepted: 6 September 2012 Published: 14 September 2012

\section{References}

1. Trayhurn P, Wood IS: Adipokines: Inflammation and the pleiotropic role of white adipose tissue. Br J Nutr 2004, 92:347-355.

2. Lago F, Dieguez C, Gomez-Reino J, Gualillo O: The emerging role of adipokines as mediators of inflammation and immune responses. Cytokine Growth Factor Rev. 2007, 18:313-325.

3. Fantuzzi G: Adipose tissue, adipokines, and inflammation. J Allergy Clin Immunol 2005, 115:911-919. quiz 920.

4. Otero M, Lago R, Gomez R, Dieguez C, Lago F, Gomez-Reino J, Gualillo O: Towards a pro-inflammatory and immunomodulatory emerging role of leptin. Rheumatology (Oxford). 2006, 45:944-950.

5. Bone RC, Balk RA, Cerra FB, Dellinger RP, Fein AM, Knaus WA, Schein RM, Sibbald WJ: Definitions for sepsis and organ failure and guidelines for the use of innovative therapies in sepsis. The accp/sccm consensus conference committee. American college of chest physicians/society of critical care medicine. Chest 1992, 101:1644-1655.

6. Levy MM, Fink MP, Marshall JC, Abraham E, Angus D, Cook D, Cohen J, Opal SM, Vincent JL, Ramsay G: $2001 \mathrm{sccm} / \mathrm{esicm} / \mathrm{accp} / \mathrm{ats} / \mathrm{sis}$ international sepsis definitions conference. Crit Care Med 2003, 31:1250-1256.

7. Angus DC, Linde-Zwirble WT, Lidicker J, Clermont G, Carcillo J, Pinsky MR: Epidemiology of severe sepsis in the united states: Analysis of incidence, outcome, and associated costs of care. Crit Care Med 2001, 29:1303-1310.

8. Angus DC, Pereira CA, Silva E: Epidemiology of severe sepsis around the world. Endocr Metab Immune Disord Drug Targets. 2006, 6:207-212.

9. Dhainaut JF, Shorr AF, Macias WL, Kollef MJ, Levi M, Reinhart K, Nelson DR: Dynamic evolution of coagulopathy in the first day of severe sepsis: Relationship with mortality and organ failure. Crit Care Med 2005, 33:341-348.

10. Koch A, Weiskirchen R, Zimmermann HW, Sanson E, Trautwein C, Tacke F: Relevance of serum leptin and leptin-receptor concentrations in critically ill patients. Mediators Inflamm 2010, :pii:473540.

11. Yousef AA, Amr YM, Suliman GA: The diagnostic value of serum leptin monitoring and its correlation with tumor necrosis factor-alpha in critically ill patients: A prospective observational study. Crit Care 2010, 14:R33.

12. Hillenbrand A, Knippschild U, Weiss M, Schrezenmeier $H$, Henne-Bruns D, Huber-Lang M, Wolf AM: Sepsis induced changes of adipokines and cytokines - septic patients compared to morbidly obese patients. BMC Surg 2010, 10:26.

13. Langouche L, Vander Perre S, Frystyk J, Flyvbjerg A, Hansen TK, Van den Berghe G: Adiponectin, retinol-binding protein 4, and leptin in protracted critical illness of pulmonary origin. Crit Care 2009, 13:R112.

14. Esmon CT, Taylor FB Jr, Snow TR: Inflammation and coagulation: Linked processes potentially regulated through a common pathway mediated by protein c. Thromb Haemost 1991, 66:160-165.

15. Joyce DE, Grinnell BW: Recombinant human activated protein c attenuates the inflammatory response in endothelium and monocytes by modulating nuclear factor-kappa b. Crit Care Med 2002, 30:S288-293.

16. Cheng T, Liu D, Griffin JH, Fernandez JA, Castellino F, Rosen ED, Fukudome K, Zlokovic BV: Activated protein c blocks p53-mediated apoptosis in ischemic human brain endothelium and is neuroprotective. Nat Med. 2003, 9:338-342.
17. Brueckmann M, Huhle G, Max M: [mechanisms of action of recombinant human activated protein c]. Anaesthesist 2006, 55(Suppl 1):5-15.

18. Brueckmann M, Hoffmann U, De Rossi L, Weiler HM, Liebe V, Lang S, Kaden J, Borggrefe M, Haase KK, Huhle G: Activated protein c inhibits the release of macrophage inflammatory protein-1-alpha from thp-1 cells and from human monocytes. Cytokine 2004, 26:106-113.

19. Brueckmann M, Hoffmann U, Dvortsak E, Lang S, Kaden JJ, Borggrefe M, Haase KK: Drotrecogin alfa (activated) inhibits nf-kappa b activation and mip-1-alpha release from isolated mononuclear cells of patients with severe sepsis. Inflamm Res 2004, 53:528-533.

20. Brueckmann M, Horn S, Lang S, Fukudome K, Schulze Nahrup A, Hoffmann U, Kaden JJ, Borggrefe M, Haase KK, Huhle G: Recombinant human activated protein c upregulates cyclooxygenase-2 expression in endothelial cells via binding to endothelial cell protein c receptor and activation of proteaseactivated receptor-1. Thromb Haemost 2005, 93:743-750.

21. Brueckmann M, Marx A, Weiler HM, Liebe V, Lang S, Kaden JJ, Zieger W, Borggrefe M, Huhle G, Konstantin Haase K: Stabilization of monocyte chemoattractant protein-1-mrna by activated protein c. Thromb Haemost 2003, 89:149-160.

22. Vandesompele J, De Preter K, Pattyn F, Poppe B, Van Roy N, De Paepe A, Speleman F: Accurate normalization of real-time quantitative rt-pcr data by geometric averaging of multiple internal control genes. Genome Biol 2002, 3:RESEARCH0034

23. Schmittgen TD, Livak KJ: Analyzing real-time pcr data by the comparative $c(t)$ method. Nat Protoc 2008, 3:1101-1108.

24. Livak KJ: Comparative Ct method. ABI Prism 7700 Sequence Detection System. User Bulletin no. 2. PE Applied Biosystems. 1997,

25. Dieffenbach CW, Dveksler GS (Eds): PCR primer, a laboratory manual. 2nd edition. New York: Cold Spring Harbor Laboratory Press; 2003.

26. Knaus WA, Draper EA, Wagner DP, Zimmerman JE: Apache ii: A severity of disease classification system. Crit Care Med 1985, 13:818-829.

27. Hughes M: Recombinant human activated protein c. Int J Antimicrob Agents 2006, 28:90-94

28. Bernard GR, Vincent JL, Laterre PF, LaRosa SP, Dhainaut JF, Lopez-Rodriguez A, Steingrub JS, Garber GE, Helterbrand JD, Ely EW, Fisher CJ Jr: Efficacy and safety of recombinant human activated protein c for severe sepsis. $N$ Engl J Med 2001, 344:699-709.

29. Quantikine ${ }^{\circledR}$ : human leptin Immunoassay. Minneapolis, USA: R\&D Systems Inc; 2009. internet-address: http://www.rndsystems.com/pdf/dlp00.pdf.

30. Fawcett RL, Waechter AS, Williams LB, Zhang P, Louie R, Jones R, Inman M, Huse J, Considine RV: Tumor necrosis factor-alpha inhibits leptin production in subcutaneous and omental adipocytes from morbidly obese humans. J Clin Endocrinol Metab 2000, 85:530-535.

31. Granowitz EV: Transforming growth factor-beta enhances and proinflammatory cytokines inhibit ob gene expression in 3 t3-l1 adipocytes. Biochem Biophys Res Commun 1997, 240:382-385.

32. Laharrague $P$, Truel N, Fontanilles AM, Corberand JX, Penicaud L, Casteilla L: Regulation by cytokines of leptin expression in human bone marrow adipocytes. Horm Metab Res 2000, 32:381-385.

33. Yamaguchi M, Murakami T, Tomimatsu T, Nishio Y, Mitsuda N, Kanzaki T, Kurachi H, Shima K, Aono T, Murata Y: Autocrine inhibition of leptin production by tumor necrosis factor-alpha (tnf-alpha) through tnf-alpha type-i receptor in vitro. Biochem Biophys Res Commun 1998, 244:30-34.

34. Gottschling-Zeller H, Birgel M, Scriba D, Blum WF, Hauner H: Depot-specific release of leptin from subcutaneous and omental adipocytes in suspension culture: Effect of tumor necrosis factor-alpha and transforming growth factor-beta1. Eur J Endocrinol 1999, 141:436-442.

35. Gerhardt CC, Romero IA, Cancello R, Camoin L, Strosberg AD: Chemokines control fat accumulation and leptin secretion by cultured human adipocytes. Mol Cell Endocrinol 2001, 175:81-92.

36. Sarraf $P$, Frederich RC, Turner EM, Ma G, Jaskowiak NT, Rivet DJ 3rd, Flier JS Lowell BB, Fraker DL, Alexander HR: Multiple cytokines and acute inflammation raise mouse leptin levels: Potential role in inflammatory anorexia. J Exp Med. 1997, 185:171-175.

37. Arnalich F, Lopez J, Codoceo R, Jim nez M, Madero R, Montiel C: Relationship of plasma leptin to plasma cytokines and human survivalin sepsis and septic shock. J Infect Dis 1999, 180:908-911.

38. Bornstein SR, Licinio J, Tauchnitz R, Engelmann L, Negrao AB, Gold P, Chrousos GP: Plasma leptin levels are increased in survivors of acute sepsis: Associated loss of diurnal rhythm, in cortisol and leptin secretion. J Clin Endocrinol Metab 1998, 83:280-283. 
39. Maruna P, Gurlich R, Frasko R, Haluzik M: Serum leptin levels in septic men correlate well with c-reactive protein (crp) and tnf-alpha but not with bmi. Physiol Res 2001, 50:589-594.

40. Nylen ES, Alarifi AA: Humoral markers of severity and prognosis of critical illness. Best Pract Res Clin Endocrinol Metab. 2001, 15:553-573.

41. Torpy DJ, Bornstein SR, Chrousos GP: Leptin and interleukin-6 in sepsis. Horm Metab Res 1998, 30:726-729.

42. Loffreda S, Yang $\mathrm{SQ}$, Lin $\mathrm{HZ}$, Karp CL, Brengman ML, Wang DJ, Klein AS, Bulkley GB, Bao C, Noble PW, Lane MD, Diehl AM: Leptin regulates proinflammatory immune responses. FASEB J 1998, 12:57-65.

43. Behnes M, Brueckmann M, Liebe V, Liebetrau C, Lang S, Putensen C, Borggrefe $M$, Hoffmann U: Levels of oxidized low-density lipoproteins are increased in patients with severe sepsis. J Crit Care. 2008, 23:537-541.

44. Behnes M, Brueckmann M, Wiessner M, Kettenmann E, Liebetrau C, Lang S, Putensen C, Borggrefe M, Hoffmann U: Time-course of neopterin levels in patients suffering from severe sepsis treated with and without drotrecogin-alpha (activated). Scand J Infect Dis 2008, 40:503-508.

45. Behnes M, Brueckmann M, Lang S, Putensen C, Saur J, Borggrefe M, Hoffmann U: Alterations of adiponectin in the course of inflammation and severe sepsis. Shock 2012, 38:243-248.

46. Shapiro NI, Khankin EV, Van Meurs M, Shih SC, Lu S, Yano M, Castro PR, Maratos-Flier E, Parikh SM, Karumanchi SA, Yano K: Leptin exacerbates sepsis-mediated morbidity and mortality. J Immunol, 185:517-524.

doi:10.1186/1471-2334-12-217

Cite this article as: Behnes et al: Alterations of leptin in the course of inflammation and severe sepsis. BMC Infectious Diseases 2012 12:217.

\section{Submit your next manuscript to BioMed Central and take full advantage of:}

- Convenient online submission

- Thorough peer review

- No space constraints or color figure charges

- Immediate publication on acceptance

- Inclusion in PubMed, CAS, Scopus and Google Scholar

- Research which is freely available for redistribution 